\title{
DOKUMENTACJA FOTOGRAFICZNA ARCHIWÓW KOŚCIELNYCH JAKO MATERIAL ILUSTRACYJNY SLOWNIKA BIOGRAFICZNEGO KSIĘŻY DIECEZJI SANDOMIERSKIEJ XIX-XX WIEKU
}

\begin{abstract}
Streszczenie
Artykuł omawia wykorzystanie dokumentacji fotograficznej archiwów kościelnych w Słowniku biograficznym księży diecezji sandomierskiej XIX-XX w. Leksykon opublikowany został w latach 2014-2019. Zawiera on 1901 biogramów duchowieństwa sandomierskiego. Ponad połowa z nich uzupełniona została reprodukcjami fotografii, prezentującymi wizerunki poszczególnych kapłanów. Większość z nich odnaleziona została podczas kwerendy w Archiwum Diecezji Sandomierskiej oraz Bibliotece Seminarium Duchownego w Sandomierzu. Autor analizuje poszczególne dokumenty źródłowe, które zawierały obiekty zdjęciowe. Dodatkowo ukazana została metoda wyboru ilustracji oraz perspektywy badawcze. Artykuł może stać się wskazówką dla autorów, którzy będą tworzyć podobne słowniki biograficzne.

Słowa kluczowe: słownik biograficzny; fotografia; archiwa kościelne; duchowieństwo diecezji sandomierskiej
\end{abstract}

\section{Wstęp}

Jednym z ważnych źródeł poznania historia, a szczególnie ludzi, którzy ją tworzyli, są słowniki biograficzne. Wiesław Bieńkowski, wybitny krakowski historyk i bibliotekoznawca, autor i redaktor wielu leksykonów biograficznych, pisał o nich w sposób następujący: „Biogramy nie tylko porządkują informacje zawarte w literaturze przedmiotu, ale poprzedzone często rozległymi kwerendami

* Ks. Piotr Tylec - dr historii Kościoła, Instytut Nauk Teologicznych, Katolicki Uniwersytet Lubelski Jana Pawła II

e-mail: piotr.tylec@kul.pl

https://orcid.org/ 0000-0002-4090-2602 
źródłowymi, przeważnie posuwają naprzód stan wiedzy"1. Początków polskiej leksykografii biograficznej należy poszukiwać już w XVI wieku (m.in. wykaz pisarzy kanonika warmińskiego Stanisława Reszki z 1594 r.). Kolejne tego typu wydawnictwa powstawały w XVII i XVIII wieku, a szczególny ich rozwój nastąpił w okresie pozytywizmu. Natomiast najważniejszym współczesnym przedsięwzięciem z zakresu tej leksykografii jest Polski słownik biograficzny. Dzieło podjęte przez Władysława Konopczyńskiego w 1931 r. realizowane jest do chwili obecnej $^{2}$. Oprócz słowników o charakterze ogólnym wydawano liczne leksykony dziedzinowe i specjalistyczne, zawierające życiorysy przedstawicieli różnych grup zawodowych czy społecznych. Zaliczyć należy do nich również i te, które poświęcone były osobom duchownym. Najstarsze z nich wydawane były jeszcze w XIX wieku i na początku następnego stulecia ${ }^{3}$. W ostatnich latach zaczęły powstawać kolejne takie publikacje, a zwłaszcza dotyczące kapłanów poszczególnych diecezji ${ }^{4}$ oraz wspólnot zakonnych ${ }^{5}$. Wpisuje się w nie również czterotomowy Stownik biograficzny księży diecezji sandomierskiej XIX-XX w. ${ }^{6}$ Cechą

${ }^{1}$ W. Bieńkowski, Biografistyka w badaniach nad ksiązka, w: Ksiązka polska w okresie zaborów, Kraków 1991, s. 50.

${ }^{2}$ M. Rzadkowolska, Polskie stowniki biograficzne - próba charakterystyki, „Forum Bibliotek Medycznych", 4 (2011) nr 2 (8), s. 244-246.

${ }^{3}$ Zob. m.in.: L. Łętowski, Katalog biskupów, prałatów i kanoników krakowskich, t. 1-2, Kraków 1852-1853; J. Korytkowski, Prałaci i kanonicy katedry metropolitalnej gnieźnieńskiej od roku 1000 aż do dni naszych. Podtug źródet archiwalnych, Gniezno 1883; J. Korytkowski, Arcybiskupi gnieźnieńscy, prymasowie i metropolici polscy od roku 1000 aż do roku 1821, czyli do połaczenia arcybiskupstwa gnieźnieńskiego z biskupstwem poznańskim. Wedtug źródeł archiwalnych, t. 1-4, Poznań 1888-1891; J. Wiśniewski, Katalog prałatów i kanoników sandomierskich od 1186 do 1926 tudzież sesje Kapituty Sandomierskiej od 1581 do 1866 r., Radom 1928; A. Bastrzykowski, Kolegiata św. Marcina w Opatowie i jej kapituła, cz. 2, Katalog prałatów i kanoników kolegiaty opatowskiej od 1212 roku aż do dni naszych, Ostrowiec [Świętokrzyski] 1948.

${ }^{4}$ Zob. m.in.: H. Mross, Stownik biograficzny kapłanów Diecezji Chetmińskiej wyświęconych w latach 1821-1920, Pelpin 1995; A. Nadolny, Stownik biograficzny kapłanów wyświęconych w latach 1921-1945 pracujacych w diecezji chetmińskiej, Pelpin 2021; A. Nowak, Stownik biograficzny kapłanów diecezji tarnowskiej 1786-1985, t. 1-4, Tarnów 1999-2004; J. Myszor, D. Bednarski, Stownik biograficzny duchowieństwa (archi)diecezji katowickiej 1922-2008, Katowice 2009; J. Kiedos, S. Lubaszka, S. Zawada, P. Greger, Stownik biograficzny zmarlych kapłanów w diecezji bielsko-żywieckiej 1992-2011, Bielsko-Biała 2012; R. Kufel, Stownik biograficzny księży pracujących w Kościele gorzowskim 1945-1956, t. 1-4, Zielona Góra 2016-2019.

${ }^{5}$ Zob. m.in.: J. Wycisło, Stownik biograficzny Misjonarzy Zgromadzenia Świętego Wincentego a Paulo ziemi pszczyńskiej, Kraków 2003; W sercu Jezusa zasnęli. Życiorysy zmarlych polskich sercanów, t. 1, 1918-1964, t. 2, 1969-1983, Kraków 2007; S. Tylus, Leksykon polskich pallotynów (1915-2012), Poznań 2013.

${ }^{6}$ B. Stanaszek, R. Nowakowski, Słownik biograficzny księży diecezji sandomierskiej XIX-XX w., t. 1, A-G, Sandomierz 2014 (dalej: SBK, t. 1); B. Stanaszek, R. Nowakowski, Stownik biograficzny księży diecezji sandomierskiej XIX-XX w., t. 2, H-t, Sandomierz 2015 (dalej: SBK, t. 2); B. Stanaszek, R. Nowakowski, P. Tylec, Stownik biograficzny księży diecezji sandomierskiej XIX-XX w., t. 3, $M-R$, Sandomierz 2017 (dalej: SBK, t. 3); B. Stanaszek, R. Nowakowski, P. Tylec, Stownik biograficzny księży diecezji sandomierskiej XIX-XX w., t. 4, S-Ż, biskupi, uzupetnienia, Sandomierz 2019 (dalej: SBK, t. 4). 
charakterystyczną leksykonów duchowieństwa, które wydane były w ostatnich latach, jest to, że oprócz informacji biograficznych posiadają one reprodukcje fotografii poszczególnych postaci.

Celem artykułu jest prezentacja materiału ilustracyjnego, który wykorzystany został w Stowniku biograficznym księży diecezji sandomierskiej XIX-XX w. (dalej w tekście: Słownik). Przede wszystkim poszukiwana będzie odpowiedź na pytanie, na ile przydatna w tej kwestii była dokumentacja archiwów kościelnych. Nie bez znaczenia będą również zagadnienia, w której z tych instytucji odnaleźć można najwięcej fotografii duchowieństwa i jakie materiały źródłowe zostały poddane kwerendzie. Dodatkowo autor postara się ukazać sposób doboru materiału zdjęciowego do poszczególnych biogramów oraz najważniejsze problemy, z którymi borykał się podczas tworzenia elementu ilustracyjnego Słownika.

Dotychczas nie powstała jeszcze żadna poważniejsza recenzja Słownika, która poruszałaby również kwestię jego materiału ilustracyjnego. Zagadnienie to nie było także omawiane we wstępach do poszczególnych tomów ${ }^{7}$. Ponieważ autorem niniejszego artykułu, jak również odpowiedzialnym za dobór fotografii wykorzystanych w Stowniku, jest ta sama osoba, podejmowany problem ukazany zostanie z perspektywy badacza. $Z$ jednej strony ułatwi to choćby prezentację sposobów wyboru materiału ilustracyjnego czy problemów związanych z kwerendą, ale nie pozwoli na całkowicie obiektywną ocenę wykonanego dzieła. Z przytoczonego powyżej powodu autor nie prowadził dodatkowych poszukiwań archiwalnych ${ }^{8}$, a wykorzystał jedynie posiadane dotychczas dokumenty źródłowe. Uzupełnione zostały one opracowaniami na temat diecezji sandomierskiej oraz historii fotografii. Artykuł składa się z trzech części: informacji ogólnych dotyczących Słownika, charakterystyki materiału ilustracyjnego oraz kwestii wykorzystania dokumentacji archiwów kościelnych przy wyborze zdjęć.

\section{Proces tworzenia oraz układ Słownika biograficznego księży diecezji san- domierskiej XIX-XX wieku}

W 2018 r. diecezja sandomierska obchodziła dwusetną rocznicę swojego istnienia. Erygowana została bowiem bullą Piusa VII Ex imposita nobis z 30 czerwca 1818 r. ${ }^{9} \mathrm{~W}$ ramach przygotowań do jubileuszu podjęto szereg inicjatyw, zarów-

${ }^{7}$ We wprowadzeniu do dwóch pierwszych tomów znalazła się jedynie następująca wzmianka: „Ks. Piotr Tylec sporo trudu włożył w zgromadzenie dokumentacji fotograficznej”. SBK, t. 1, s. 8; SBK, t. 2, s. 8.

${ }^{8}$ Ponieważ autor jest dyrektorem Archiwum Diecezji Sandomierskiej, jak również Biblioteki Diecezjalnej w Sandomierzu, stale rozwija wiedzę o zasobach tych instytucji. Dużo informacji, również o istniejących fotografiach, przynosi porządkowanie zespołu akt Kurii Diecezji w Sandomierzu (w tym także akt personalnych kapłanów) w ramach programu Naczelnej Dyrekcji Archiwów Państwowych - Wspieranie działań archiwalnych. Projekt ten realizowany jest sukcesywnie od 2019 r., a jego wynikiem jest tworzony inwentarz. Zob. Inwentarz zespolu archiwalnego Kuria Diecezjalna w Sandomierzu [XVII] 1818-2019, Sandomierz 1818-2019, https://bdsandomierz.pl/inwentarz.pdf (dostęp: 20.09.2021)

${ }^{9}$ Zob. Bulla papieża Piusa VII o erekcji diecezji sandomierskiej, oprac. i thum. H. Wójtowicz, „Kronika Diecezji Sandomierskiej”, 61 (1968) nr 3, s. 65-72. 
no o charakterze religijnym, jak i naukowym, kulturalnym i wydawniczym. Z tej racji ukazało się kilka okolicznościowych publikacji, m.in. Rocznik Jubileuszowy Diecezji Sandomierskiej ${ }^{10}$, pozycje albumowe ${ }^{11}$, przewodnik ${ }^{12}$ oraz monografie naukowe ${ }^{13}$. Wzbogacił je również czterotomowy Słownik biograficzny księży diecezji sandomierskiej $X I X-X X$ w. $^{14}$ Dzieło to powstało w latach 2014-2019, choć pierwsze przygotowania do jego publikacji podjęto na przełomie 2012 i 2013 r. $^{15}$ Jego autorami są: ks. prof. dr hab. Bogdan Stanaszek (Wydział Historii i Dziedzictwa Kulturowego Uniwersytetu Papieskiego Jana Pawła II w Krakowie), ks. mgr Ryszard Nowakowski (były pracownik Archiwum Diecezji Sandomierskiej) oraz ks. dr Piotr Tylec (dyrektor Biblioteki Diecezjalnej w Sandomierzu), który dołączył do składu redakcyjnego przy tworzeniu trzeciego i czwartego tomu. Całość projektu współfinansowana była $z$ dotacji na utrzymanie potencjału badawczego Uniwersytetu Papieskiego Jana Pawła II w Krakowie, przyznanej przez Ministra Nauki i Szkolnictwa Wyższego w latach 2014-2018.

Pierwszy tom Stownika ukazał się w 2014 r. Znalazły się w nim biogramy księży, których nazwiska rozpoczynały się od litery A do litery G. Łącznie zawarto w nim 473 życiorysów duchownych ${ }^{16}$. Drugi tom wydany został w $2015 \mathrm{r}$. i obejmował 390 sylwetek kapłanów (litery H-Ł) ${ }^{17}$. Kolejny opublikowany został w 2017 r. Spośród księży o nazwiskach zaczynających na na litery od M do R opisano $438^{18}$. Natomiast czwarty tom, który ukazał się w 2019 r., objął ostatnią grupę duchownych (S-Ż) oraz biogramy biskupów i uzupełnia, i prezentuje 600 życiorysó $w^{19}$. Łącznie dzieło obejmuje 1901 sylwetek kapłanów i biskupów diecezji sandomierskiej.

Autorzy podczas pisania Stownika opierali się przede wszystkim na materiałach źródłowych, które przechowywane są w Archiwum Diecezji Sandomierskiej. Spośród nich najważniejszymi były akta personalne duchowieństwa. Dokumentacja dotycząca poszczególnych księży zbierana była od chwili ich wstąpienia do seminarium duchownego, a następnie w okresie przygotowania do kapłaństwa (życiorys, podania, zaświadczenia o święceniach). Po święceniach prezbiteratu

${ }^{10}$ Rocznik Jubileuszowy Diecezji Sandomierskiej, red. R. Janiec, P. Tylec, B. Krzos, S. Gurba, Sandomierz 2018.

${ }^{11}$ B. Stanaszek, Diecezja sandomierska 1818-2018. Tradycje historyczne, Sandomierz 2018; Ziemia mówiąca Bogu tak. 200 lat diecezji sandomierskiej, Sandomierz 2019.

${ }^{12}$ B. Krzos, Przewodnik po dziejach diecezji sandomierskiej, Sandomierz [2018].

${ }^{13}$ R. Pomerańska, Z dziedzictwem w przyszłość. 200 lat diecezji sandomierskiej, Sandomierz 2018; E. Orzechowska, Duchowieństwo diecezji sandomierskiej w Powstaniu Styczniowym, Sandomierz 2018.

${ }^{14}$ We wstępie do pierwszego tomu autorzy napisali: „Zbliżający się jubileusz 200-lecia utworzenia diecezji sandomierskiej (1818-2018) składnia do zintensyfikowania badań związanych z jej przeszłością. Niniejsza publikacji wpisuje się w ten nurt”. SBK, t. 1, s. 5.

${ }^{15}$ Kartoteka duchowieństwa, „Gość Niedzielny”, 2019 nr 43, dodatek „Gość Sandomierski”, s. VI.

${ }^{16}$ SBK, t. 1, s. 11-272.

${ }^{17}$ SBK, t. 2, s. 11-227.

${ }^{18}$ SBK, t. 3, s. 11-258.

${ }^{19}$ SBK, t. 4, s. 11-366. 
przekazywana była do kancelarii Konsystorza Biskupiego (od 1919 r. Kurii Diecezjalnej). Dodawano do niej różnorakie dokumenty, m.in. nominacje na placówki duszpasterskie oraz korespondencję z biskupem i urzędnikami kościelnymi. We wspomnianej kancelarii materiały te przechowywane były aż do śmierci duchownego, po czym trafiały do archiwum konsystorskiego (kurialnego). Oprócz akt personalnych autorzy wykorzystali również inne materiały ze wspomnianego archiwum, m.in. akta służby i śmierci kapłanów, wizytacji dziekańskich oraz księgi posług biskupich. Dodatkowo ks. Bogdan Stanaszek uzupełnił biogramy o informacje źródłowe zaczerpnięte z innych archiwów (m.in. Archiwum Akt Nowych w Warszawie, Centralnego Archiwum Wojskowego w Rembertowie, akt IPN), które zebrał podczas wcześniejszych kwerend naukowych ${ }^{20}$. Materiały archiwalne autorzy uzupełnili dostępnymi publikacjami, szczególnie autorstwa ks. Jana Wiśniewskiego ${ }^{21}$, bpa Piotra Kubickiego ${ }^{22}$, ks. Stanisława Kotkowskie$\mathrm{go}^{23}$ oraz ks. Aleksandra Bastrzykowskiego ${ }^{24}$, jak również nekrologami zawartymi w „Kronice Diecezji Sandomierskiej” ${ }^{25}$.

Poszczególne biogramy mają stały schemat, o ile pozwalały na to zebrane informacje. Nagłówek tworzą: nazwisko i imię, lata życia, rok przyjęcia święceń kapłańskich oraz ewentualna przynależność do zakonu (wraz z imieniem zakonnym). W pierwszej części znajdują się wiadomości biograficzne, tj. data i miejsce urodzenia, imiona rodziców i ich przynależność stanowa, wykształcenie (podstawowe, średnie, inne), ukończone seminarium duchowne wraz z okresem pobytu w nim oraz datą święceń subdiakonatu (od t. 3), diakonatu oraz prezbiteratu. Kolejny fragment ukazuje przebieg pracy duszpasterskiej (ewentualnie naukowej,

${ }^{20}$ Wynikiem kwerend archiwalnych ks. Bogdana Stanaszka są m.in. następujące pozycje: $D u$ chowieństwo diecezji sandomierskiej w latach 1918-1939, Lublin 1999; Diecezja sandomierska w powojennej rzeczywistości politycznej w latach 1945-1967, t. 1, Problematyka personalno-organizacyjna, t. 2, Duszpasterstwo i laicyzacja życia społecznego, Sandomierz 2006; Księża diecezji sandomierskiej więzieni przez władze komunistyczne po II wojnie światowej, Rzeszów 2008.

${ }^{21}$ J. Wiśniewski, Seminarjum Duchowne Rzym.-Katol. w Sandomierzu 1820-1920 oraz stuletni katalog duchowieństwa świeckiego diecezji sandomierskiej, Sandomierz 1926 oraz seria książek dotycząca poszczególnych dekanatów diecezji sandomierskiej.

${ }^{22}$ P. Kubicki, Bojownicy kapłani za sprawę Kościoła i ojczyzny w latach 1861-1915, cz. 1, Dawne Królestwo Polskie, t. 3, Diecezje: sandomierska, sejneńska, warszawska, emigracja kleru po r. 1863, zakony, zestawienia i spisy, Sandomierz 1933; P. Kubicki, Bojownicy kaptani za sprawe Kościoła i ojczyzny w latach 1861-1915. Materialu z urzędowych świadectw władz rosyjskich, archiwów konsystorskich, zakonnych i prywatnych, cz. 2, Dawna Litwa i Białoruś, t. 1, Przedmowa, źródta i pomoce, wstęp zawierający okólniki rządu rosyjskiego krępujące wolność Kościoła i uciemiężające ducha narodowego i bojownicy za sprawę Kościoła, kler świecki i zakonny, Sandomierz 1936.

${ }^{23}$ S. Kotkowski, Seminarium Duchowne w Sandomierzu w latach 1820-1926, oprac. i przygotowała do druku H. Szumił, Sandomierz 2010.

${ }^{24}$ Bastrzykowski, Kolegiata św. Marcina w Opatowie i jej Kapituła, Ostrowiec Świętokrzyski 1948; Bastrzykowski, Kolegiata św. Marcina oraz monografie parafii Kunów, Jankowice Kościelne, Góry Wysokie oraz Ruda Kościelna.

${ }^{25}$ Kartoteka duchowieństwa, s. VI-VII; SBK, t. 1, s. 6-7, 273-277; SBK, t. 2, s. 5-7, 228-233; SBK, t. 3, s. 5-7, 259-265; SBK, t. 4, s. 6-7, 368-375. 
urzędniczej, wojskowej), szczególnie daty nominacji na poszczególne stanowiska i funkcje. Kończy go informacja o dacie śmierci i miejscu pochówku. W trzeciej części zawarto wiadomości o dokonaniach duchownego, a są to m.in. budowa budynków sakralnych i kościelnych, działalność naukowa, publicystyczna i społeczna, oraz uzyskanych przez niego odznaczeniach kościelnych i państwowych. Biogram kończy się wykazem źródeł i opracowań, które wykorzystano przy jego tworzeniu ${ }^{26}$. Znaczna część haseł została opatrzona reprodukcją fotografii, co zostanie szczegółowo omówione w niniejszym artykule.

\section{Materiał ilustracyjny}

Ilustracja encyklopedyczna pełni ważną funkcję poznawczą, zwłaszcza w przypadku obiektów technicznych, elementów fauny i flory czy miejsc geograficznych ${ }^{27}$. Natomiast w przypadku słowników biograficznych pozwala na swego rodzaju „ożywienie” poszczególnych postaci. Czytelnik nie tylko dowiaduje się, kim była opisywana osoba, lecz także może zobaczyć jej wygląd, co ma dodatkowy walor emocjonalny.

W Słowniku wyborem i reprodukcją fotografii kapłanów diecezji sandomierskiej zajął się ks. Piotr Tylec, autor niniejszego artykułu. W przeważającej większości duchowni posiadali tylko jedno zdjęcie, co upraszczało dobór odpowiedniej ilustracji. Natomiast w przypadku, kiedy dany ksiądz posiadał więcej niż jedną fotografię, zastosowano następującą metodę wyboru. Pierwszym kryterium była jakość materiału źródłowego. Niekiedy zdarzało się, że zdjęcia były częściowo zniszczone, zamazane, nieostre lub nie można było wykonać ich reprodukcji (np. głęboko osadzone w poszycie akt). W takich przypadkach wybierano ilustrację w lepszym stanie zachowania. Drugim wyznacznikiem było to, czy ksiądz został uwieczniony w stroju duchownym. Pierwszeństwo miały odbitki, które miały ten właśnie walor. Ostatnim kryterium był wiek fotografowanego kapłana. Z zasady starano się nie uwzględniać tych zdjęć, które wykonano w okresie szkolnym, m.in. edukacji w Niższym Seminarium Duchownym w Sandomierzu. Pomijano też fotografie wykonane w późnej starości.

Kwerenda przeprowadzona $\mathrm{w}$ archiwach, bibliotekach, jak również w opracowaniach i zasobach internetu, pozwoliła na opatrzenie reprodukcjami fotografii 991 biogramów księży diecezji sandomierskiej, co prezentuje poniższa tabela.

${ }^{26}$ SBK, t. 1, s. 8; SBK, t. 2, s. 7-8; SBK, t. 3, s. 7-8; SBK, t. 4, s. 7-8.

${ }^{27}$ Kwestią tą zajmuje się m.in. Bożena Hojko. Zob. B. Hojko, Ilustracje w ogólnych stownikach języka polskiego, „Studia o Książce i Informacji”, 27 (2008), s. 119-133; B. Hojko, Poznawcze walory ilustracji w stownikach dla dzieci, „Bibliotheca Nostra. Śląski kwartalnik naukowy”, 2016, $\mathrm{nr}$ 1, s. 66-74; B. Hojko, Ilustracje, animacje, interaktywne obrazki-funkcje i formy elementów graficznych w stownikach internetowych, „Folia Bibliologica”, 59 (2017), s. 153-167. 
Tabela 1.

Liczba biogramów $\mathrm{z}$ reprodukcją fotografii

\begin{tabular}{|c|c|c|c|}
\hline Tom & Liczba biogramów & $\begin{array}{c}\text { Liczba biogramów } \\
\text { z reprodukcją } \\
\text { fotografii }\end{array}$ & $\begin{array}{c}\text { Procent biogramów } \\
\text { z reprodukcją } \\
\text { fotografii }\end{array}$ \\
\hline I & 473 & 233 & $49,3 \%$ \\
\hline II & 390 & 229 & $58,7 \%$ \\
\hline III & 438 & 223 & $50,9 \%$ \\
\hline IV & 600 & 306 & $51 \%$ \\
\hline Razem & $\mathbf{1 9 0 1}$ & $\mathbf{9 9 1}$ & $\mathbf{5 2 , 1} \%$ \\
\hline
\end{tabular}

Źródło: Stownik biograficzny, t. 1-4.

Spośród 1901 biogramów Słownika reprodukcję fotografii ma 991 życiorysów, co stanowi 52,1\%. Przelicznikowo najwięcej znalazło się ich w tomie drugim - 58,7\% (229 z 390), najmniej w tomie pierwszym - 49,3\% (233 z 473). Spowodowane to było tym, iż odpowiedzialny za tę inicjatywę nie posiadał pełnego dostępu do materiałów archiwalnych. Wykorzystano jedynie tę dokumentację, która została przygotowana przez pracowników Archiwum Diecezji Sandomierskiej oraz Biblioteki Diecezjalnej w Sandomierzu. W okresie przygotowywania drugiego tomu autor został zatrudniony we wspomnianych instytucjach, co pozwoliło na wyszukanie większej liczby zdjęć duchowieństwa.

Należy jednak pamiętać, iż w Stowniku znalazły się sylwetki księży, którzy zmarli w okresie, kiedy niemożliwym było jeszcze wykonanie fotografii. Pierwsze zakłady świadczące taką usługę powstawały w miastach Królestwa Polskiego w latach 60. XIX wieku ${ }^{28}$. W Kielcach, które znajdowały się w niedalekiej odległości od granic diecezji sandomierskiej, miało to miejsce w $1863 \mathrm{r}$. Wtedy to działalność rozpoczęło atelier Władysława Krajewskiego. W Radomiu pierwszy taki zakład założył ok. $1871 \mathrm{r}$. Bolesław Rzewuski, brat znanego krakowskiego fotografa Walerego Rzewuskiego. Natomiast w Sandomierzu możliwość wykonania zdjęcia nastąpiła jeszcze później, tj. po 1875 r., kiedy do miasta przybył ze Staszowa Marcin Kasiewicz. Profesjonalny zakład fotograficzny w stolicy diecezji sandomierskiej założył on jednak dopiero pod koniec $1888 \mathrm{r}^{29}$ Najstarsze dwa znane zdjęcia ukazujące duchownych wspomnianej diecezji pochodzą z 1864 r. ${ }^{30}$ Prawdopodobnie wykonane zostały w Sandomierzu, bowiem prezentują kapłanów pracujących w miejscowym konsystorzu, seminarium (wraz z alumnami) oraz kościele katedralnym. Trudno przypuszczać, że 13 księży i 18 kleryków wyjechało do Kielc bądź Warszawy celem wykonania wspólnej fotografii. Natomiast najstarsze zdjęcia portretowe należą do kapłanów, którzy zmarli w pierwszej

${ }^{28}$ R. Bogdziewicz, Fotografia na Lubelszczyźnie na tle fotografii europejskiej i krajowej w latach 1839-1918, Lublin 2017, s. 20.

${ }^{29}$ M. Janik, Fotografia w guberniach kieleckiej i radomskiej w latach 1839-1918, „Rocznik Muzeum Narodowego w Kielcach" 15 (1986/1987), s. 88, 91-92.

${ }^{30}$ J. Wiśniewski, Seminarjum Duchowne, s. 3. 
połowie lat 70. XIX wieku ${ }^{31}$. Z tej racji można założyć, że w Słowniku możliwe było wykorzystanie fotografii księży, którzy zmarli po 1870 r. ${ }^{32}$ (zob. tab. 2).

Tabela 2.

Liczba biogramów z reprodukcją fotografii - księża zmarli po 1870 r. $^{33}$

\begin{tabular}{|c|c|c|c|}
\hline Tom & $\begin{array}{c}\text { Liczba biogramów } \\
\text { księży zmarlych po } \\
\mathbf{1 8 7 0} \text { r. }\end{array}$ & $\begin{array}{c}\text { Liczba biogramów } \\
\text { z reprodukcją } \\
\text { fotografii }\end{array}$ & $\begin{array}{c}\text { Procent biogramów } \\
\text { z reprodukcją } \\
\text { fotografii }\end{array}$ \\
\hline I & 338 & 228 & $67,5 \%$ \\
\hline II & 292 & 226 & $77,4 \%$ \\
\hline III & 304 & 217 & $71,4 \%$ \\
\hline IV & 398 & 298 & $74,9 \%$ \\
\hline Razem & $\mathbf{1 3 3 2}$ & $\mathbf{9 6 9}$ & $\mathbf{7 2 , 7 \%}$ \\
\hline
\end{tabular}

Źródło: Słownik biograficzny, t. 1-4.

W Słowniku znalazły się 1332 biogramy księży, którzy zmarli po $1870 \mathrm{r}$. $\mathrm{Z}$ tej liczby 969 życiorysów posiada ilustrację zdjęciową (dodatkowo siedem reprodukcji obrazów). Tak więc spośród duchownych, którzy teoretycznie mogli mieć własną fotografię, udało się odnaleźć fotosy $72,7 \%$ z nich. Najwięcej w tomie drugim (77,4\%), a najmniej w tomie pierwszym (67,5\%). Liczba kapłanów, którzy mieli swoje zdjęcie, była zależna od okresu ich życia, co ukazuje poniższy wykres.

${ }^{31}$ Najstarsze fotografie portretowe przedstawiają księży: Wojciecha Drążkiewicza $(† 1873)$, Jana Krupińskiego (†1874), Juliana Sochackiego (†1874) oraz Szczepana Pindakiewicza $(† 1875)$. SBK, t. 1, 168; SBK, t. 2, s. 157; SBK, t. 3, s. 164; SBK, t. 4, s. 65.

${ }^{32}$ Niektórzy duchowni zmarli przed $1870 \mathrm{r}$. posiadają swoje ujęcia portretowe - są to jednak reprodukcje obrazów. Należą do nich biskupi: nominat Klemens Bąkiewicz (†1842), Adam Prosper Burzyński (†1830), sufragan Aleksander Dobrzański (†1831), Józef Goldtman (†1852), Szczepan Hołowczyc $(\dagger 1823)$ oraz księża: Józef Czekajowicz (†1831), Jakub Gierasiński (†1868), Maciej Gorelski (†1849), Stanisław Jastrzębski (†1850), Tomasz Markowski (†1855), Anastazy Pętkowski $(† 1837)$, Franciszek Przybyłowicz $(† 1863)$, Jan Ratyński $(† 1860)$, Kazimierz Stokowski $(† 1847)$, Stanisław Straszak (†1833). SBK, t. 1, s. 145, 224, 244; SBK, t. 2, s. 42; SBK, t. 3, s. 26, 153, 196, 217; SBK, t. 4, s. 90, 94, 301-302, 304, 307, 329

${ }^{33} \mathrm{~W}$ tabeli nie ujęto biogramów księży zmarłych po 1870 r., którzy mieli jedynie reprodukcję swoich obrazów. Należeli do nich: Józef Gacki (†1876), Jan Kloczkowski (†1884), Michał Kobierski ( $† 1876)$, Kacper Kotkowski ( $† 1875)$, Aleksander Malanowicz ( $† 1893)$, Antoni Misiórski (†1886), Karol Teliga (†1884). SBK, t. 1, s. 209; SBK, t. 2, s. 90, 98, 126; SBK, t. 3, s. 23, 63; SBK, t. 4 , s. 167. 


\section{Wykres 1.}

Liczba procentowa biogramów z reprodukcją fotografii - księża zmarli po 1870 r. (z podziałem na okres śmierci)

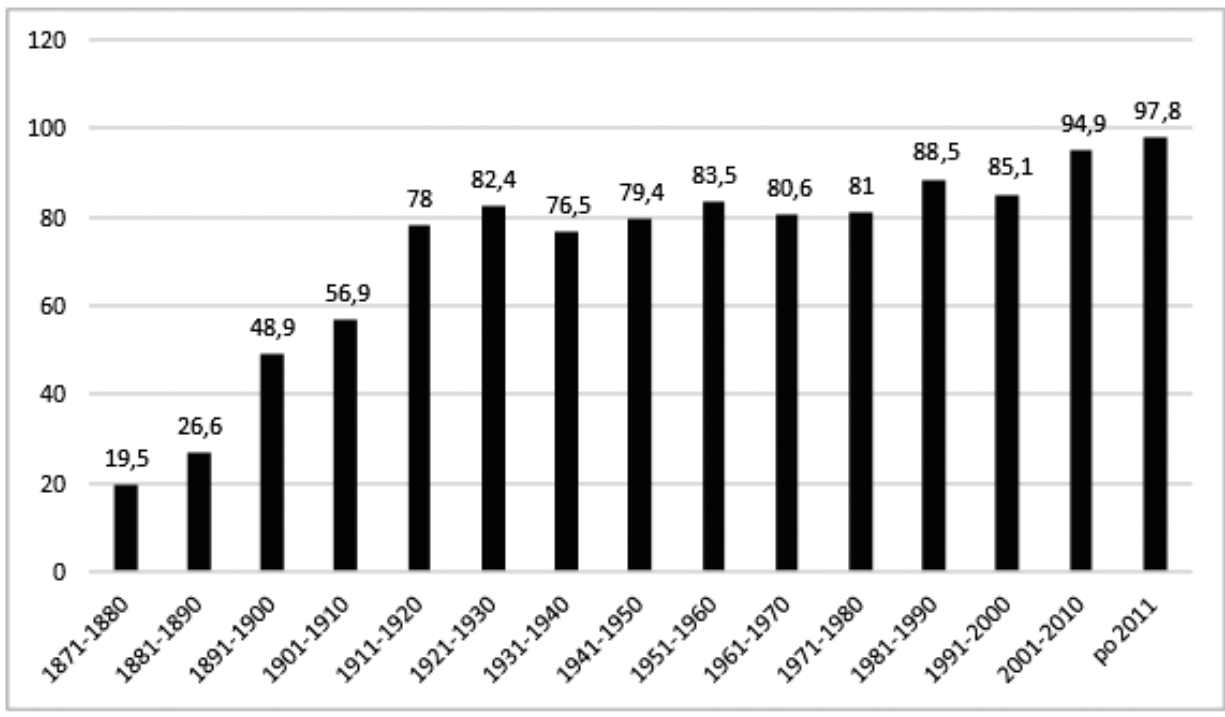

Źródło: Słownik biograficzny, t. 1-4.

Powyższy wykres wyraźnie wskazuje na tendencję: im późniejsza data śmierci duchownego, a co za tym idzie okres jego życia, tym większa szansa na to, iż w Stowniku biogram kapłana został opatrzony reprodukcją zdjęcia. Nie może to dziwić, bowiem dostępność do zakładów fotograficznych wraz z upływem czasu znacznie wzrastała, aż stała się czymś powszechnym. Dokumentacja ilustracyjna księży posługujących w diecezji sandomierskiej w XX i XXI w. w większości została odnaleziona. Duży wpływ na to miały kościelne materiały źródłowe, które zostały wykorzystane przy tworzeniu Stownika. Stanowiły one główną bazę wszystkich zaprezentowanych reprodukcji fotografii, co ukazuje poniższa tabela.

Tabela 3.

Materiały źródłowe fotografii duchowieństwa diecezji sandomierskiej

\begin{tabular}{|c|c|c|c|c|c|}
\hline \multirow{2}{*}{ Tom } & \multirow{2}{*}{$\begin{array}{c}\text { Liczba } \\
\text { biogramów }\end{array}$} & \multicolumn{2}{|c|}{$\begin{array}{c}\text { Biogramy z fotografiami } \\
\text { pochodzącymi z archiwów } \\
\text { kościelnych }\end{array}$} & \multicolumn{2}{|c|}{$\begin{array}{c}\text { Biogramy z fotografiami } \\
\text { pochodzącymi spoza } \\
\text { archiwów kościelnych }\end{array}$} \\
\cline { 3 - 6 } & & Liczba & Procent & Liczba & Procent \\
\hline I & 223 & 200 & $89,7 \%$ & 23 & $10,3 \%$ \\
\hline II & 229 & 195 & $85,1 \%$ & 34 & $14,9 \%$ \\
\hline III & 223 & 195 & $87,4 \%$ & 28 & $13,6 \%$ \\
\hline IV & 306 & 260 & $85,0 \%$ & 46 & $15,0 \%$ \\
\hline Razem & $\mathbf{9 8 1}$ & $\mathbf{8 5 0}$ & $\mathbf{8 6 , 6 \%}$ & $\mathbf{1 3 1}$ & $\mathbf{1 3 , 4 \%}$ \\
\hline
\end{tabular}

Źródło: Słownik biograficzny, t. 1-4. 
Zdecydowana większość ilustrowanych biogramów (ponad 86\%) ma reprodukcję fotografii zaczerpniętą z kościelnych materiałów źródłowych. Charakterystyka tych archiwaliów zostanie omówiona w dalszej części niniejszego artykułu. Pozostałe zdjęcia zostały odnalezione $\mathrm{w}$ archiwach pozakościelnych, zbiorach prywatnych, publikacjach książkowych i internetowych (zob. tab. 4).

Tabela 4.

Pozakościelne materiały źródłowe fotografii duchowieństwa diecezji sandomierskiej

\begin{tabular}{|c|c|c|c|c|}
\hline Tom & $\begin{array}{c}\text { Liczba } \\
\text { biogramów } \\
\text { z fotografiami } \\
\text { pochodzącymi } \\
\text { spoza archiwów } \\
\text { kościelnych }\end{array}$ & $\begin{array}{c}\text { Archiwa } \\
\text { pozakościelne, } \\
\text { zbiory } \\
\text { prywatne }\end{array}$ & $\begin{array}{c}\text { Publikacje } \\
\text { książkowe }\end{array}$ & $\begin{array}{c}\text { Źródła } \\
\text { internetowe }\end{array}$ \\
\hline I & 23 & 1 & 19 & 3 \\
\hline II & 34 & - & 32 & 2 \\
\hline III & 28 & 2 & 24 & 2 \\
\hline IV & 46 & 1 & 43 & 2 \\
\hline Razem & $\mathbf{1 3 1}$ & $\mathbf{4}$ & $\mathbf{1 1 9}$ & $\mathbf{9}$ \\
\hline
\end{tabular}

Źródło: Stownik biograficzny, t. 1-4.

Z pozakościelnych materiałów źródłowych wykorzystano przede wszystkim fotografie, które reprodukowane były w publikacjach książkowych. Najwięcej z nich znalazło się w albumie wydanym na 100-lecie Seminarium Duchownego w Sandomierzu przez ks. Jana Wiśniewskiego. Duchowny zamieścił tam bowiem kilkadziesiąt reprodukcji zdjęć związanych z uczelnią duchowną, w tym kilka tableau, które nie zachowały się w zbiorach Biblioteki Diecezjalnej w Sandomie$\mathrm{rzu}^{34}$. Kilkanaście fotografii zaczerpniętych zostało z dwóch roczników diecezji sandomierskiej, które zawierały elementy ilustracyjne ${ }^{35}$, a pozostałe z książek związanych z historii Kościoła sandomierskiego ${ }^{36}$. Ponadto wykorzystano zdjęcia z zasobów instytucji pozakościelnych: Centralnego Archiwum Wojskowego ${ }^{37}$, I LO w Dębicy ${ }^{38}$ oraz Muzeum Historyczno-archeologicznego w Ostrowcu Świętokrzyskim ${ }^{39}$. Jedną fotografię przekazał ze swoich zbiorów prywatnych ks. prof. Bogdan Stanaszek ${ }^{40}$.

${ }^{34}$ Wiśniewski, Seminarjum Duchowne, s. 2-8b (paginacja nieregularna).

${ }^{35}$ Rocznik Diecezji Sandomierskiej 1997, red. A. Kończak, Sandomierz 1998; Rocznik Diecezji Sandomierskiej 2010, red. K. Kida, Sandomierz 2010.

${ }^{36}$ M.in.: Wiśniewski, Katalog prałatów; Stanaszek, Duchowieństwo diecezji.

${ }^{37}$ SBK, t. 3, s. 136.

${ }^{38}$ SBK, t. 3, s. 97.

${ }^{39}$ SBK, t. 4, s. 134.

${ }^{40}$ SBK, t. 1, s. 251. 


\section{Charakterystyka dokumentacji fotograficznej archiwów kościelnych}

Jak zostało wspomniane, zdecydowana większość fotografii duchowieństwa, która stała się elementem ilustracyjnym Stownika, pochodziła z archiwów kościelnych. Gdyby doliczyć do niej reprodukcje z albumu ks. Wiśniewskiego oraz roczników diecezjalnych, które przecież też pochodziły z tychże zbiorów (m.in. archiwum bieżącego Kurii Diecezjalnej w Sandomierzu), to byłoby to ok. $98 \%$ wszystkich zamieszczonych zdjęć. Dokumentacja fotograficzna odnaleziona została przede wszystkim w dwóch instytucjach kościelnych: Archiwum Diecezji Sandomierskiej oraz Bibliotece Diecezjalnej w Sandomierzu (zob. tab. 5).

Tabela 5.

Instytucje kościelne gromadzące dokumentację zawierającą fotografie duchowieństwa diecezji sandomierskiej

\begin{tabular}{|c|c|c|c|c|c|c|}
\hline \multirow{2}{*}{ Tom } & \multicolumn{2}{|c|}{$\begin{array}{c}\text { Archiwum Diecezji } \\
\text { Sandomierskiej }\end{array}$} & \multicolumn{2}{c|}{$\begin{array}{c}\text { Biblioteka } \\
\text { Diecezjalna } \\
\text { W Sandomierzu }\end{array}$} & \multicolumn{2}{|c|}{$\begin{array}{c}\text { Inne instytucje } \\
\text { kościelne }\end{array}$} \\
\cline { 2 - 7 } & Liczba & Procent & Liczba & Procent & Liczba & Procent \\
\hline I & 81 & $40,5 \%$ & 117 & $58,5 \%$ & 2 & $1,0 \%$ \\
\hline II & 64 & $32,8 \%$ & 130 & $66,7 \%$ & 1 & $0,5 \%$ \\
\hline III & 69 & $35,4 \%$ & 125 & $64,1 \%$ & 1 & $0,5 \%$ \\
\hline IV & 109 & $41,9 \%$ & 148 & $56,9 \%$ & 3 & $1,2 \%$ \\
\hline Razem & $\mathbf{3 2 3}$ & $\mathbf{3 8 , 0 \%}$ & $\mathbf{5 2 0}$ & $\mathbf{6 1 , 8 \%}$ & 7 & $\mathbf{0 , 8 \%}$ \\
\hline
\end{tabular}

Źródło: Słownik biograficzny, t. 1-4.

Ponad 99\% fotografii zaczerpniętych z kościelnych instytucji pochodziło z dwóch głównych jednostek archiwalno-bibliotecznych diecezji sandomierskiej. Siedem pozostałych zdjęć odnaleziono w: Archiwum Parafii Bidziny (przekazał je ks. Dariusz Socha) ${ }^{41}$, Wyższym Seminarium Duchownym w Sandomierzu (tableau wiszace na jednym z korytarzy $)^{42}$ oraz Wydawnictwie Diecezjalnym i Drukarni w Sandomierzu (fotografie biskupów wykorzystane we wcześniejszych publikacjach $)^{43}$. Ze względu na specyfikę zbiorów Archiwum Diecezji Sandomierskiej oraz Biblioteki Diecezjalnej w Sandomierzu zostaną one omówione osobno.

\section{Archiwum Diecezji Sandomierskiej}

Archiwum Diecezji Sandomierskiej, które funkcjonowało pod różnymi nazwami (Archiwum Konsystorza Biskupiego, Archiwum Diecezjalne), zostało założone w 1819 r. Gromadzi ono przede wszystkim spuściznę Kurii Diecezjalnej w Sandomierzu, choć znajduje się w nim również inna dokumentacja (m.in. duplikaty ksiąg metrykalnych parafii diecezji sandomierskiej wytworzone po 1946 r.,

\footnotetext{
${ }^{41}$ SBK, t. 3, s. 86.

${ }^{42}$ SBK, t. 1, s. 159; SBK, t. 2, s. 136.

${ }^{43}$ SBK, t. 4, s. 324, 334, 336.
} 
materiały dotyczące domów księży demerytów z XIX wieku i inne) ${ }^{44}$. Z tegoż archiwum wykorzystano jedynie fotografie znajdujące się w teczkach personalnych kapłanów. Instytucja ta posiada kilkadziesiąt albumów ze zdjęciami, jednak prezentują one przede wszystkim uroczystości kościelne, które odbywały się po $1945 \mathrm{r}$. $\mathrm{Z}$ tej racji można odnaleźć na nich głównie księży, którzy mają fotografie portretowe w innych źródłach. Poza tym albumy nie zawierają podpisów pod zdjęciami, przez co identyfikacja niektórych duchownych staje się prawie niemożliwa.

W teczkach personalnych księży diecezji sandomierskiej znajduje się około 400 fotografii, z czego w Słowniku wykorzystano 323 ujęcia. Odnaleźć je można w różnego rodzaju dokumentacji, co prezentuje poniższa tabela.

Tabela 7.

Rodzaje dokumentacji personalnej księży diecezji sandomierskiej zawierające fotografie

\begin{tabular}{|c|c|c|c|c|c|c|c|}
\hline \multirow[t]{4}{*}{ Tom } & \multicolumn{4}{|c|}{ Świadectwa szkolne } & \multirow{3}{*}{$\begin{array}{c}\text { Karty } \\
\text { personalne }\end{array}$} & \multirow{3}{*}{$\begin{array}{c}\text { Legitymacje, } \\
\text { dyplomy }\end{array}$} & \multirow{3}{*}{$\begin{array}{c}\text { Fotografie } \\
\text { "luźne" }\end{array}$} \\
\hline & \multirow{2}{*}{$\begin{array}{c}\text { Do } \\
1914 \text { r. }\end{array}$} & \multicolumn{2}{|c|}{ 1918-1939 } & \multirow{2}{*}{$\begin{array}{c}\text { Po } \\
1945 \text { r. } \\
\end{array}$} & & & \\
\hline & & NSD & Pozostale & & & & \\
\hline & 18 & 28 & 9 & 10 & 10 & 4 & 3 \\
\hline II & 10 & 13 & 11 & 17 & 4 & 4 & 5 \\
\hline III & 8 & 22 & 10 & 17 & 6 & 1 & 6 \\
\hline IV & 24 & 26 & 13 & 23 & 14 & 5 & 4 \\
\hline Razem & 60 & 87 & 43 & 67 & 34 & 14 & 18 \\
\hline
\end{tabular}

Źródło: Słownik biograficzny, t. 1-4.

Najwięcej fotografii w teczkach personalnych duchowieństwa sandomierskiego odnaleźć można na świadectwach szkolnych (maturalnych), tj. 79,6\% wszystkich wykorzystanych jednostek archiwalnych. Dokument ten składany był podczas rekrutacji do seminarium duchownego, a po święceniach kapłańskich przekazywany do miejscowego konsystorza/kurii. Znajduje się on w zdecydowanej większości akt personalnych księży, którzy posługiwali w diecezji sandomierskiej od lat 90. XIX wieku.

Od końca XIX wieku aż do pierwszej wojny światowej fotografie na świadectwach szkolnych znajdowały się na specjalnie doszytych kartonikach. Zazwyczaj miały one również urzędową pieczęć. Tego typu ujęcia znalazły się w Słowniku przy 60 biogramach. Najstarsze z nich pochodzi z $1890 \mathrm{r}$. i znalazło się na świadectwie Juliana Lipińskiego, który ukończył Progimnazjum w Łomży ${ }^{45}$. Z ostatniej dekady XIX wieku takich fotografii odnaleziono zaledwie dziesięćc ${ }^{46}$. Wykonane były one głównie jako odbitki kolodionowe. Pozostałe, które dołączono do

${ }^{44}$ Zob. P. Tylec, Wstę, w: Inwentarz zespolu archiwalnego Kuria Diecezjalna w Sandomierzu [XVII] 1818-2019, Sandomierz 2019-2020, s. 3-16; bdsandomierz.pl/inwentarz.pdf (dostęp: 20.09.2021)

${ }^{45}$ SBK, t. 2, s. 208.

${ }^{46}$ SBK, t. 1, s. 11, 25, 101-102; SBK, t. 2, s. 208; SBK, t. 3, s. 181; SBK, t. 4, s. 18, 80, 99, 257. 
dokumentacji szkolnej z lat 1901-1914, przeważnie sporządzono techniką srebrowo-żelazową ${ }^{47}$.

Duża liczba fotografii (130 szt.) znalazła się na świadectwach szkolnych z okresu międzywojennego. Ponad $2 / 3$ z nich wydanych zostało przez Prywatne Gimnazjum Kurii Diecezjalnej w Sandomierzu, nazywane również niższym seminarium ${ }^{48}$. Większość uczniów tej szkoły zostawała później klerykami miejscowej wyższej uczelni duchownej, a następnie kapłanami diecezji sandomierskiej. Podczas formacji gimnazjalnej zobowiązani byli do noszenia sutanny. $Z$ tej racji zdjęcia na tych świadectwach ukazują przyszłych księży w stroju duchownym. Fotografie te pochodzą z okresu od 1926 do 1938 r. $^{49}$ Pozostałe wykorzystane świadectwa pochodzą z publicznych placówek oświatowych, stąd kandydaci do seminarium fotografowani byli w ubiorach świeckich ${ }^{50}$. Podobny charakter posiadają zdjęcia, które znalazły się na dokumentacji szkolnej wytworzonej po $1945 \mathrm{r}$. W Słowniku wykorzystano ich przy ilustracji 67 życiorysów.

Pozostałe zdjęcia, które pochodzą z teczek personalnych duchowieństwa diecezji sandomierskiej, znalazły się na tzw. kartach personalnych, legitymacjach, dyplomach oraz jako osobne obiekty. Karty personalne znajdują się w aktach kapłanów, którzy przed podziałem administracyjnym Kościoła katolickiego w Polsce w 1992 r., pracowali w diecezji przemyskiej (31 szt.) oraz lubelskiej $(3 \mathrm{szt} .)^{51}$. Arkusz ten, wykonany na twardym papierze, umieszczano na początku dokumentacji personalnej. Znajdowały się tam podstawowe informacje dotyczące poszczególnych duchownych, tj. imię i nazwisko, data i miejsce urodzenie, dane rodziców, przebieg edukacji i formacji seminaryjnej, przyjęte święcenia, ewentualne dalsze wykształcenie oraz uzupełniany na bieżąco przebieg pracy duszpasterskiej. Karta posiadała również miejsce na fotografię, która ukazywała kapłana w stroju duchownym ${ }^{52}$. W 14 przypadkach biogramy Słownika ilustrowano zdjęciami, które znajdowały się na legitymacjach (w głównej mierze tzw. kapłańskich $)^{53}$. Dodatkowo kilka fotografii zaczerpnięto z dyplomów magisterskich, które księża uzyskiwali na studiach specjalistycznych (m.in. na Uniwersytecie Jagiellońskim w Krakowie, Akademii Teologii Katolickiej w Warszawie oraz Katolickim Uniwersytecie Lubelskim w Lublinie $)^{54}$. Kilkanaście zdjęć zostało dołą-

${ }^{47}$ Zob. M. Gołąb, Srebrowe techniki fotograficzne, „Ochrona Zabytków”, 35 (1982) nr 1-2, s. $45-46$.

${ }^{48}$ Zob. R. Rędzio, Prywatne Gimnazjum Kurii Diecezjalnej w Sandomierzu w latach 19281938, Lublin-Sandomierz 2019, praca mgr. w zbiorach Biblioteki Diecezjalnej w Sandomierzu.

${ }^{49}$ SBK, t. 1, s. 53; SBK, t. 3, s. 124.

${ }^{50}$ Tylko w przypadku Kazimierza Petryszaka, który ukończył Gimnazjum w Tłumaczu (19201926), użyto na świadectwie fotografii, na której ubrany był on w strój duchowny. SBK, t. 3, s. 152.

${ }^{51} \mathrm{~W}$ wyniku ustaleń zawartych w bulli Jana Pawła II Totus Tuus Poloniae Populus z 25 marca 1992 r. diecezja sandomiersko-radomska zmieniła swoje dotychczasowe granice. Znalazły się w niej fragmenty diecezji: macierzystej sandomiersko-radomskiej, przemyskiej, lubelskiej i tarnowskiej. Wielu kapłanów, którzy pracowali w parafiach wspomnianych jednostek kościelnych, inkardynowało się do diecezji sandomierskiej. Pomerańska, Z dziedzictwem, Sandomierz 2018, s. 24.

${ }^{52}$ M.in.: SBK, t. 1, s. 54, 96; SBK, t. 4, s. 361.

${ }^{53}$ M.in.: SBK, t. 2, s. 100; SBK, t. 4, s. 20, 249.

${ }^{54}$ SBK, t. 1, s. 96; SBK, t. 3, s. 125; SBK, t. 4, s. 47, 239. 
czonych do akt personalnych jako osobne obiekty. Zazwyczaj nie były to jednak fotografie portretowe, ale prezentujące kapłana podczas pracy duszpasterskiej, społecznej itp..$^{55}$

\section{Biblioteka Diecezjalna w Sandomierzu}

Biblioteka Diecezjalna w Sandomierzu swoimi początkami sięga 1820 r., a więc czasu, kiedy utworzone zostało miejscowe seminarium duchowne. Oprócz książek gromadzi ona zbiory archiwalne, $\mathrm{w}$ tym również o charakterze niepiśmiennym, tj. grafiki, mapy oraz fotografie ${ }^{56}$. Zasób zdjęciowy obejmuje kilkanaście tysięcy obiektów. Zespół ten nie jest jednak uporządkowany, co znacznie utrudnia jego prezentację. Dla potrzeb Stownika wyodrębniono trzy grupy źródeł ilustracyjnych, w których można odnaleźć ujęcia księży diecezji sandomierskiej: spuścizna po ks. Janie Wiśniewskim, tableau oraz zespół fotografii. Wykorzystanie zdjęć z poszczególnych grup prezentuje tabela poniżej.

Tabela 7.

Materiały archiwalne Biblioteki Diecezjalnej w Sandomierzu zawierające fotografie kapłanów

\begin{tabular}{|l|c|c|c|c|c|c|}
\hline \multirow{2}{*}{ Tom } & $\begin{array}{c}\text { Spuścizna po ks. Janie } \\
\text { Wiśniewskim }\end{array}$ & \multicolumn{2}{|c|}{ Tableau } & \multicolumn{2}{|c|}{ Zespól fotografii } \\
\cline { 2 - 7 } & Liczba & Procent & Liczba & Procent & Liczba & Procent \\
\hline I & 23 & $20,3 \%$ & 21 & $18,6 \%$ & 69 & $61,1 \%$ \\
\hline II & 7 & $5,4 \%$ & 42 & $32,5 \%$ & 80 & $62,1 \%$ \\
\hline III & 25 & $20,2 \%$ & 37 & $29,8 \%$ & 62 & $50,0 \%$ \\
\hline IV & 24 & $15,6 \%$ & 14 & $9,1 \%$ & 116 & $75,0 \%$ \\
\hline Razem & $\mathbf{7 9}$ & $\mathbf{1 5 , 2 \%}$ & $\mathbf{1 1 4}$ & $\mathbf{2 1 , 9 \%}$ & $\mathbf{3 2 7}$ & $\mathbf{6 2 , 9 \%}$ \\
\hline
\end{tabular}

Źródło: Słownik biograficzny, t. 1-4.

W Słowniku wykorzystano 520 reprodukcji zdjęć, które znajdują się w zasobie Biblioteki Diecezjalnej w Sandomierzu. Najwięcej z nich pochodzi z szeroko pojętego zespołu fotografii (62,9\%). Pozostałe to ilustracje z tableau (21,9\%) oraz materiały znajdujące się w spuściźnie po ks. Janie Wiśniewskim. Te ostatnie wyodrębnione zostały z ogólnego zespołu fotografii ze względu na to, że ten znany regionalista, kolekcjoner i historyk amator ${ }^{57}$, opisywał własne zbiory ${ }^{58}$. Adnotacje te pozwalają na identyfikację poszczególnych duchownych. Szczególnie pomoc-

${ }^{55}$ SBK, t. 1, s. 75, 80; SBK, t. 2, s. 81; SBK, t. 3, s. 150; SBK, t. 4, s. 36, 251.

${ }^{56}$ Zob. P. Tylec, Biblioteka Diecezjalna w Sandomierzu, „Zeszyty Sandomierskie”, 24 (2018) $\mathrm{nr}$ 45, s. 35-41; P. Tylec, Biblioteka Diecezjalna w Sandomierzu - historia i teraźniejszość, „Fides. Biuletyn Bibliotek Kościelnych”, 25 (2019) nr 2 (49), s. 131-156.

${ }^{57}$ Zob. J. Fidos, D. Olszewski, Ksiądz Jan Wiśniewski 1876-1943. Życie i działalność, Kielce 2000; W. Wójcik, Ks. Jan Wiśniewski (1876-1943), „Archiwa, Biblioteki i Muzea Kościelne”, 6 (1963) s. 279-294.

${ }^{58}$ U. Stępień, Działalność kolekcjonerska ks. Jana Wiśniewskiego, na tle zainteresowań przeszłościa środowiska kościelnego w Sandomierzu przełomu XIX/XX wieku, „Archiwa, Biblioteki i Muzea Kościelne”, 6 (1963) s. 284. 
ne okazało się to przy zdjęciach zbiorowych ${ }^{59}$. Zdecydowana większość fotografii tej spuścizny wykonana została w XIX wieku, posiada format gabinetowy $\mathrm{i}$ jest odbitką na papierze kolodionowym ${ }^{60}$.

Ponad 100 reprodukcji, które stały się elementem ilustracyjnym biogramów kapłanów diecezji sandomierskiej, zostało zaczerpnięte z pamiątkowych tableau. Większość z nich prezentuje alumnów wraz z gronem profesorskim sandomierskiego seminarium. Najstarsze wykonane zostało w 1876 r. ${ }^{61}$ Kolejne pochodzą z 1881, 1886, 1892, 1902, 1907, 1918, 1926 i 1930 r. Przez długie lata, aż do czasu remontu gmachu seminaryjnego w latach 1998-1999, wisiały one na korytarzach. Trzy ostatnie nie zachowały się w całości. Odklejono jedynie część zdjęć portretowych, które złożono w oddzielnych kopertach (większość z nich zachowała się w bardzo słabym stanie ${ }^{62}$ ). W sandomierskiej uczelni duchownej powstały jeszcze dwa tableau o nieco innym charakterze. Pierwsze z nich ukazuje alumnów przynależących do koła społecznego. Drugie poświęcone jest cenionemu profesorowi, ks. Janowi Gajkowskiemu ${ }^{63}$. W zbiorach Biblioteki Diecezjalnej zachowały się również dwa tableau, które kapłani dedykowali zasłużonym duchownym: ks. Stanisławowi Bernatowiczowi i ks. Józefowi Urbańskiemu. Ze względu na to, iż posiadały one mniej zdjęć portretowych, wykorzystane były wyłącznie w drugim tomie Stownika ${ }^{64}$.

Wszystkie pozostałe zdjęcia, które gromadzi w swoim archiwum Biblioteka Diecezjalna w Sandomierzu, opisane zostały jako „zbiór fotografii”. Z tej racji w Słowniku znalazło się najwięcej reprodukcji z tejże grupy, tj. 327 (więcej niż z wszystkich teczek personalnych kapłanów). Przede wszystkim są to fotografie portretowe, które uporządkował długoletni opiekun książnicy, ks. Andrzej Wyrzykowski ${ }^{65}$. Podzielił je na dziesięć części i spakował w specjalne płócienne worki. Większość zdjęć zabezpieczona została tekturowymi passe-partout, na których znalazły się personalia duchownych. Niektóre z nich uzupełniono również innymi informacjami, a są to m.in. lata życia, data wykonania odbitki, krótkie biogramy itp. ${ }^{66}$ Inną grupę fotografii stanowią te, które zgromadzone zostały w kilku albumach. Niestety tylko część z nich posiada podpisy, które pozwalają na identyfika-

${ }^{59}$ M.in. SBK, t. 1, s. 136, 163, 262; SBK, t. 3, s. 11, 15, 81, 105, 108, 163, 168, 187; SBK, t. 4, s. 19, 79, 96, 164, 196, 267, 281, 289, 293.

${ }^{60}$ M.in. SBK, t. 1 , s. $28,83,244-245$; SBK, t. 2, s. $16,82,86,196$; SBK, t. 3, s. 60, 141, 229; SBK, t. 4, s. 23, 130, 169, 201, 234, 248.

${ }^{61}$ Zachowała się jedynie reprodukcja zdjęciowa tegoż tableau, która użyta została w albumie na stulecie seminarium. Wiśniewski, Seminarjum Duchowne, s. 4.

${ }^{62}$ M.in. SBK, t. 1, s. 39, 113, 135, 178, 202, 260; SBK, t. 2, s. 36, 68, 95, 147, 165, 169, 226; SBK, t. 3, s. 34, 61, 162, 233; SBK, t. 4, s. 58, 91, 107, 195, 201, 241, 287.

${ }^{63}$ Zob. Ks. Jan Gajkowski (1866-1919). Kapłan - pisarz - społecznik. Materiaty z sesji. Sandomierz, 22 października 1999 r., red. K. Burek, Sandomierz 2000.

${ }^{64}$ SBK, t. 2, s. 78, 203.

${ }^{65}$ Zob. W. Wójcik, Ks. Andrzej Wyrzykowski (1879-1955), „Archiwa, Biblioteki i Muzea Kościelne", 2 (1961) nr 1-2, s. 298-302.

${ }^{66}$ Większość fotografii portretowych opisał ks. Andrzej Wyrzykowski, choć można znaleźć również styl pisma innych osób. W zespole tym znalazło się również kilkadziesiąt obiektów, które nie są zdjęciami, tj. wycinki prasowe, kartki pocztowe, obrazki, a nawet klisze. 
cję poszczególnych księży ${ }^{67}$. Oprócz tego wykorzystano kilkanaście pudeł, które zawierają kilka tysięcy nieuporządkowanych zdjęć. Wśród nich szczególnie skupiono się na tych, które prezentowały osoby duchowne. Były to zarówno ujęcia portretowe, jak i fotografie grupowe. W przypadku wykonanych opisów możliwe stało się wykorzystanie ich do ilustracji biogramów Słownika ${ }^{68}$.

\section{Podsumowanie}

Ważne miejsce w Stowniku biograficznym księży diecezji sandomierskiej XIX$-X X w$. pełni element ilustracyjny. Uzupełnia on informacje, które zawarte zostały w poszczególnych życiorysach. Czterotomowy leksykon prezentuje 1901 biogramów duchowieństwa sandomierskiego. Ponad połowa z nich $(52,1 \%-991)$ uzupełniona jest reprodukcjami fotografii. Współczynnik ten wzrasta o ponad $20 \%$ (do 72,7\%), kiedy wyeliminujemy sylwetki kapłanów żyjących przed możliwością ich sfotografowania. Zdecydowana większość wykorzystanych zdjęć odnaleziona została w materiałach źródłowych archiwów kościelnych $(86,6 \%)$. Pozostałe pochodziły głównie z publikacji książkowych. Przy założeniu, że ich autorzy korzystali również z niedostępnych dziś zbiorów kościelnych (m.in. zniszczone podczas remontów seminaryjne tableau, archiwum bieżące Kurii Diecezjalnej w Sandomierzu), to odsetek ten wzrasta do ok. 98\%. Instytucjami, które przechowują wspomniane materiały, są przede wszystkim Archiwum Diecezji Sandomierskiej oraz Biblioteka Diecezjalna w Sandomierzu. W pierwszej z nich wykorzystano teczki personalne kapłanów. Odnaleziono w nich ok. 400 fotografii, z czego w Słowniku użyto 323. Najwięcej z nich znajdowało się na świadectwach szkolnych (prawie 80\%). Pozostałe pochodziły z kart personalnych, legitymacji oraz dyplomów. Kilkanaście teczek zawierało zdjęcia jako osobne elementy. Znacznie więcej fotografii wyszukano podczas kwerendy w Bibliotece Diecezjalnej w Sandomierzu. W leksykonie wykorzystano aż 520 reprodukcji zdjęć z tej książnicy. Wszystkie pochodziły z kilkunastotysięcznego zespołu fotografii. Część z nich wyodrębniono jako spuściznę znanego kolekcjonera i regionalisty ks. J. Wiśniewskiego. Zdjęcia te prezentują przede wszystkim duchownych żyjących w XIX wieku, co stało się niezwykle cennym elementem ilustracyjnym Słownika. Inna grupę tworzą pamiątkowe tableau, szczególnie te, które nie były wcześniej publikowane.

Podsumowując, należy stwierdzić, iż bez wykorzystania dokumentacji fotograficznej archiwów kościelnych nie byłoby możliwe zilustrowanie Słownika biograficznego księży diecezji sandomierskiej XIX-XX w. Bardzo wyraźnym dowodem jest $\mathrm{w}$ tym przypadku pierwszy tom leksykonu. Wykonujący reprodukcje zdjęć nie posiadał wówczas pełnego dostępu do zbiorów wspomnianych instytucji kościelnych. Tym samym znalazło się w nim znacznie mniej ilustracji niż w to-

${ }^{67}$ M.in. SBK, t. 1, s. 129 , 142, 262; SBK, t. 2, s. $13,74,77,119$, 224; SBK, t. 3, s. $84,90,96$; SBK, t. 4 , s. $53,89$.

${ }^{68}$ M.in. SBK, t. 1, s. 50, 64, 68, 107, 147, 154, 236; SBK, t. 2, s. 22, 30, 33, 75, 87, 97,109, 112 , 137, 146, 168, 190, 194, 198, 202, 217; SBK, t. 3, s. 13, 26, 37, 56, 129, 184, 244, 246; SBK, t. 4, s. $12,30,40,57,118,139,142,155,173,180,194,246,261,268$. 
mach następnych. Od chwili zakończenia tworzenia Słownika udało się odnaleźć kilkanaście fotografii duchownych, których biogramy nie posiadały tego elementu. Dodatkowo kilka reprodukcji zdjęć księży zostało przesłanych do Biblioteki Diecezjalnej w Sandomierzu przez regionalistów, którzy zapoznali się z leksykonem i podzielili się swoimi zbiorami. Być może fotografie te zostaną wykorzystane w przyszłości przy kolejnych wydaniach Stownika.

\section{REFERENCES / BIBLIOGRAFIA}

\section{Źródła}

Bulla papieża Piusa VII o erekcji diecezji sandomierskiej, oprac. i thum. H. Wójtowicz, „Kronika Diecezji Sandomierskiej”, 61 (1968) nr 3, s. 65-72.

Inwentarz zespolu archiwalnego Kuria Diecezjalna w Sandomierzu [XVII] 1818-2019, Sandomierz 1818-2019, https://bdsandomierz.pl/inwentarz.pdf (dostęp: 20.09.2021)

Kartoteka duchowieństwa, „Gość Niedzielny”, 2019 nr 43, dodatek „Gość Sandomierski”, s. VI-VII.

Rocznik Diecezji Sandomierskiej 1997, red. A. Kończak, Sandomierz 1998.

Rocznik Diecezji Sandomierskiej 2010, red. K. Kida, Sandomierz 2010.

Rocznik Jubileuszowy Diecezji Sandomierskiej, red. R. Janiec, P. Tylec, B. Krzos, S. Gurba, Sandomierz 2018.

Stanaszek Bogdan, Nowakowski Ryszard, Stownik biograficzny księży diecezji sandomierskiej XIX-XX w., t. 1, $A-G$, Sandomierz 2014.

Stanaszek Bogdan, Nowakowski Ryszard, Stownik biograficzny księży diecezji sandomierskiej XIX-XX w., t. 2, $H$ - $\ell$, Sandomierz 2015.

Stanaszek Bogdan, Nowakowski Ryszard, Tylec Piotr, Słownik biograficzny księży diecezji sandomierskiej $X I X-X X$ w., t. 3, $M-R$, Sandomierz 2017.

Stanaszek Bogdan, Nowakowski Ryszard, Tylec Piotr, Słownik biograficzny księży diecezji sandomierskiej XIX-XX w., t. 4, S-Ż, biskupi, uzupetnienia, Sandomierz 2019.

\section{Opracowania}

Bastrzykowski Aleksander, Kolegiata św. Marcina w Opatowie i jej Kapituła, Ostrowiec Świętokrzyski 1948.

Bastrzykowski Aleksander, Kolegiata św. Marcina w Opatowie i jej kapituła, cz. 2, Katalog prałatów i kanoników kolegiaty opatowskiej od 1212 roku aż do dni naszych, Ostrowiec Świętokrzyski 1948.

Bieńkowski Wiesław, Biografistyka w badaniach nad książka, w: Książka polska w okresie zaborów, Kraków 1991, s. 41-59.

Bogdziewicz Ryszard, Fotografia na Lubelszczyźnie na tle fotografii europejskiej i krajowej w latach 1839-1918, Lublin 2017.

Fidos Jarosław, Olszewski Daniel, Ksiądz Jan Wiśniewski 1876-1943. Życie i działalność, Kielce 2000.

Gołąb Marta, Srebrowe techniki fotograficzne, „Ochrona Zabytków”, 35 (1982) nr 1-2, s. $45-52$.

Hojko Bożena, Ilustracje w ogólnych stownikach języka polskiego, „Studia o Książce i Informacji”, 27 (2008) s. 119-133.

Hojko Bożena, Poznawcze walory ilustracji w stownikach dla dzieci, „Bibliotheca Nostra. Śląski kwartalnik naukowy”, (2016) nr 1, s. 66-74. 
Hojko Bożena, Ilustracje, animacje, interaktywne obrazki - funkcje i formy elementów graficznych w stownikach internetowych, „Folia Bibliologica”, 59 (2017) s. 153-167.

Janik Maciej, Fotografia $w$ guberniach kieleckiej i radomskiej $w$ latach 1839-1918, „Rocznik Muzeum Narodowego w Kielcach”, 15 (1986/1987) s. 85-139.

Kiedos Józef, Lubaszka Stanisław, Zawada Sławomir, Greger Piotr, Słownik biograficzny zmarłych kapłanów w diecezji bielsko-żywieckiej 1992-2011, Bielsko-Biała 2012.

Korytkowski Jan, Arcybiskupi gnieźnieńscy, prymasowie i metropolici polscy od roku 1000 aż do roku 1821, czyli do połaczenia arcybiskupstwa gnieźnieńskiego z biskupstwem poznańskim. Wedtug źródet archiwalnych, t. 1-4, Poznań 1888-1891.

Korytkowski Jan, Prałaci i kanonicy katedry metropolitalnej gnieźnieńskiej od roku 1000 aż do dnia naszych. Podtug źródet archiwalnych, Gniezno 1883.

Kotkowski Stanisław, Seminarium Duchowne w Sandomierzu w latach 1820-1926, oprac. i przygotowała do druku H. Szumił, Sandomierz 2010.

Krzos Bartłomiej, Przewodnik po dziejach diecezji sandomierskiej, Sandomierz [2018].

Ks. Jan Gajkowski (1866-1919). Kaptan - pisarz - społecznik. Materiały z sesji. Sandomierz, 22 października 1999 r., red. K. Burek, Sandomierz 2000.

Kubicki Paweł, Bojownicy kapłani za sprawę Kościoła i ojczyzny w latach 1861-1915, cz. 1, Dawne Królestwo Polskie, t. 3, Diecezje: sandomierska, sejneńska, warszawska, emigracja kleru po r. 1863, zakony, zestawienia i spisy, Sandomierz 1933.

Kubicki Paweł, Bojownicy kapłani za sprawę Kościoła i ojczyzny w latach 1861-1915. Materiatu z urzędowych świadectw władz rosyjskich, archiwów konsystorskich, zakonnych i prywatnych, cz. 2, Dawna Litwa i Białoruś, t. 1, Przedmowa, źródta i pomoce, wstęp zawierajacy okólniki rząu rosyjskiego krępujace wolność Kościoła i uciemiężajace ducha narodowego i bojownicy za sprawę Kościoła, kler świecki $i$ zakonny, Sandomierz 1936.

Kufel Robert, Słownik biograficzny księży pracujących w Kościele gorzowskim 19451956, t. 1-4, Zielona Góra 2016-2019.

Łętowski Ludwik, Katalog biskupów, prałatów i kanoników krakowskich, t. 1-2, Kraków 1852-1853.

Mross Henryk, Słownik biograficzny kapłanów Diecezji Chetmińskiej wyświęconych w latach 1821-1920, Pelpin 1995.

Myszor Jerzy, Bednarski Damian, Stownik biograficzny duchowieństwa (archi)diecezji katowickiej 1922-2008, Katowice 2009.

Nadolny Anastazy, Słownik biograficzny kapłanów wyświęconych w latach 1921-1945 pracujacych $w$ diecezji chetmińskiej, Pelpin 2021.

Nowak Adam, Słownik biograficzny kapłanów diecezji tarnowskiej 1786-1985, t. 1-4, Tarnów 1999-2004.

Orzechowska Elżbieta, Duchowieństwo diecezji sandomierskiej w Powstaniu Styczniowym, Sandomierz 2018.

Pomerańska Renata, $Z$ dziedzictwem w przyszłość. 200 lat diecezji sandomierskiej, Sandomierz 2018.

Rędzio Robert, Prywatne Gimnazjum Kurii Diecezjalnej w Sandomierzu w latach 19281938, Lublin-Sandomierz 2019, praca mgr. w zbiorach Biblioteki Diecezjalnej w Sandomierzu.

Rzadkowolska Magdalena, Polskie słowniki biograficzne - próba charakterystyki, „Forum Bibliotek Medycznych", 4 (2011) nr 2 (8), s. 243-298.

Stanaszek Bogdan, Diecezja sandomierska 1818-2018. Tradycje historyczne, Sandomierz 2018. 
Stanaszek Bogdan, Diecezja sandomierska w powojennej rzeczywistości politycznej w latach 1945-1967, t. 1, Problematyka personalno-organizacyjna, t. 2, Duszpasterstwo i laicyzacja życia społecznego, Sandomierz 2006.

Stanaszek Bogdan, Duchowieństwo diecezji sandomierskiej w latach 1918-1939, Lublin 1999.

Stanaszek Bogdan, Księża diecezji sandomierskiej więzieni przez władze komunistyczne po II wojnie światowej, Rzeszów 2008.

Stępień Urszula, Działalność kolekcjonerska ks. Jana Wiśniewskiego, na tle zainteresowań przeszłościa środowiska kościelnego w Sandomierzu przełomu XIX/XX wieku, „Archiwa, Biblioteki i Muzea Kościelne”, 6 (1963) s. 269-295.

Tylec Piotr, Biblioteka Diecezjalna w Sandomierzu, „Zeszyty Sandomierskie”, 24 (2018) nr 45, s. 35-41.

Tylec Piotr, Biblioteka Diecezjalna w Sandomierzu - historia i teraźniejszość, „Fides. Biuletyn Bibliotek Kościelnych", 25 (2019) nr 2 (49), s. 131-156.

Tylec Piotr, Wstep, w: Inwentarz zespolu archiwalnego Kuria Diecezjalna w Sandomierzu [XVII] 1818-2019, Sandomierz 2019-2020, s. 3-16; bdsandomierz.pl/inwentarz.pdf (dostęp: 20.09.2021)

Tylus Stanisław, Leksykon polskich pallotynów (1915-2012), Poznań 2013.

W sercu Jezusa zasnęli. Życiorysy zmartych polskich sercanów, t. 1, 1918-1964, t. 2, 19691983, Kraków 2007.

Wiśniewski Jan, Katalog prałatów i kanoników sandomierskich od 1186 do 1926 tudzież sesje Kapituty Sandomierskiej od 1581 do 1866 r., Radom 1928.

Wiśniewski Jan, Seminarjum Duchowne Rzym.-Katol. w Sandomierzu 1820-1920 oraz stuletni katalog duchowieństwa świeckiego diecezji sandomierskiej, Sandomierz 1926.

Wójcik Walenty, Ks. Andrzej Wyrzykowski (1879-1955), „Archiwa, Biblioteki i Muzea Kościelne", 2 (1961) nr 1-2, s. 298-302.

Wójcik Walenty, Ks. Jan Wiśniewski (1876-1943), „Archiwa, Biblioteki i Muzea Kościelne", 6 (1963), s. 279-294.

Wycisło Janusz, Słownik biograficzny Misjonarzy Zgromadzenia Świętego Wincentego a Paulo ziemi pszczyńskiej, Kraków 2003.

Ziemia mówiąca Bogu tak. 200 lat diecezji sandomierskiej, Sandomierz 2019. 


\title{
PHOTOGRAPHIC DOCUMENTATION OF CHURCH ARCHIVES AS ILLUSTRATIVE MATERIAL OF BIOGRAPHICAL DICTIONARY OF PRIESTS FROM THE DIOCESE OF SANDOMIERZ OF THE 19TH- 20TH CENTURIES
}

\begin{abstract}
This article discusses the use of photographic documentation of the church archives of Biographical dictionary of priests from the Diocese of Sandomierz of the 19th-20th centuries. The lexicon was published in years 2014-2019. It contains 1901 biographical notes of the Sandomierz clergy. More than half of them were supplemented with photo reproductions presenting the images of individual priests. Most of them were found during searches in the Archives of the Diocese of Sandomierz and the Library of the Theological Seminary in Sandomierz. The author analyzes individual source documents that contained photographic objects. Additionally, the method of selecting illustrations and research perspectives were presented. The article may become a guide for authors who will create similar biographical dictionaries.
\end{abstract}

Keywords: biographical dictionary; photograph; church archives; clergy of the Diocese of Sandomierz 